\title{
Enhanced expression of hexokinase $I$ in pancreatic islets induced by sucrose administration
}

\author{
B Maiztegui*, M I Borelli*, M L Massa, H Del Zotto \\ and J J Gagliardino
}

CENEXA-Center of Experimental and Applied Endocrinology (UNLP-CONICET, PAHO/WHO Collaborating Center), National University of La Plata School of Medicine, 60 y 1201900 La Plata, Argentina

(Requests for offprints should be addressed to J J Gagliardino; Email: cenexa@speedy.com.ar)

*(B Maiztegui and M I Borelli contributed equally to this work)

\begin{abstract}
Administration of a sucrose-rich diet (SRD) to normal hamsters induces an insulin-resistant state and a significant increase of insulin secretion and $\beta$-cell mass. Islets isolated from these animals had a marked increase in glucose metabolism and glucose-induced insulin secretion, at both low and high glucose concentrations. They also presented increased hexokinase (HK) activity, without measurable changes in glucokinase (GK) activity. In this study we measured HK and GK activity in homogenates of islets isolated from normal control and SRD-fed hamsters, as well as in their particulate and cytosolic fractions. We also measured transcription rate (mRNA by reverse transcriptase PCR) and expression levels (Western blotting) of both enzymes in these islets. We found an increase in
\end{abstract}

HK activity and expression levels, without measurable changes in HK mRNA level in SRD-fed animals. Whereas a similar GK activity was measured in homogenates of islets isolated from both groups, such activity was significantly higher in the cytosolic fraction of SRD islets. On the other hand, GK transcription rate and expression level were similar in both experimental groups. Our results suggest that the increased $\beta$-cell secretory response to low glucose can be partly ascribed to an increased activity of islet HK consecutive to an enhanced expression of the enzyme, while the enhanced response to high glucose could be due to changes in GK compartmentalization.

Journal of Endocrinology (2006) 189, 311-317

\section{Introduction}

Insulin resistance is a common feature of several pathological conditions characterized by a decreased response of insulin-dependent tissues to the hormone action that triggers a reactive hyperinsulinemia to keep blood glucose levels within normal range (Reaven 1988). The lack of an appropriate release of insulin in response to glucose will result in the appearance of a diabetic syndrome (DeFronzo 1997), a serious disease with an increasing worldwide prevalence (Gagliardino \& Olivera 2000). To prevent the development of diabetes it is important to know the precise mechanisms involved in successful pancreas reactivity to cope with an increased demand of insulin secretion.

Administration of a sucrose-rich diet (SRD) to normal rats is an effective experimental model to induce insulin resistance (Cohen et al. 1977). Using this model we have previously shown that SRD administration to normal rats (Lombardo et al. 1996; Pick et al. 1998) and hamsters (Massa et al. 1997, Del Zotto et al. 1999) produces a significant increase of insulin secretion and $\beta$-cell mass. We have further shown that islets isolated from SRD-fed hamsters had increased hexokinase (HK) activity, without measurable changes in glucokinase (GK) activity, together with a marked increase of glucose metabolism in response to glucose (Massa et al. 2001). It was not clear, however, whether the changes recorded in HK activity were accompanied by parallel changes in the transcription/ expression level of this enzyme.

In an attempt to get a deeper insight into this problem, we simultaneously measured glucose-induced insulin secretion, activity (in homogenates and in their particulate and cytosolic fractions), mRNA and expression level of GK and HK in islets isolated from SRD-fed hamsters. We found that SRD-isolated islets presented a simultaneous increase in insulin secretion and HK activity and expression, without changes in HK mRNA level. We also found increased GK activity in the cytosolic fraction, without changes in its transcription/expression levels. Thus, the increased $\beta$-cell secretory response of SRD islets at low glucose could be partly ascribed to an increase in HK activity, consecutive to an enhanced protein expression of the enzyme, while the increased response to high glucose could be due to changes in GK compartmentalization. 


\section{Materials and Methods}

Chemicals and drugs

Collagenase was from Serva Feinbiochemica (Heidelberg, Germany); BSA (fraction V) and other reagents were from Sigma Chemical Co. RINm5F-GK cells were kindly provided by Professor Sigurd Lenzen (Institute of Clinical Biochemistry, Hannover Medical School, Germany).

\section{Experimental groups}

Twenty-three-day-old male Syrian hamsters $(30 \pm 2 \mathrm{~g})$ were divided into two groups. The treated group had free access to a standard commercial diet plus $10 \%$ sucrose $(\mathrm{w} / \mathrm{v})$ in their drinking water (SRD), whereas the control group (C) received the same diet and tap water for 5 weeks. Water intake was measured daily, while individual body weight was recorded once a week.

\section{Blood measurements and pancreas removal}

When the animals were killed blood samples were collected for glucose determination by the glucose oxidase GOD-PAP method (Roche Diagnostics), and for immunoreactive insulin levels by RIA (Herbert et al. 1965), using an antibody against rat insulin, rat insulin standard (Linco Research, St. Charles, MO, USA), and highly purified porcine insulin labeled with ${ }^{125} \mathrm{I}$ (Linde et al. 1980); parallel tracer-displacement curves were obtained using either the rat insulin standard, or partially purified insulin extracted from a pool of hamster pancreases (Massa et al. 1997). The pancreas from each animal was removed to isolate islets by collagenase digestion (Lacy \& Kostianovsky 1967).

\section{Insulin secretion in vitro}

Groups of five islets were incubated for $60 \mathrm{~min}$ at $37{ }^{\circ} \mathrm{C}$ in $0.6 \mathrm{ml}$ of Krebs-Ringer bicarbonate buffer, $\mathrm{pH} 7 \cdot 4$, previously gassed with $\mathrm{CO}_{2} / \mathrm{O}_{2}(5 \% / 95 \%)$, containing $1 \%$ (w/v) BSA and 3.3 or $16.7 \mathrm{mM}$ glucose (Gagliardino et al. 1974). At the end of the incubation period, aliquots were taken from the medium to measure insulin by RIA (Herbert et al. 1965, Linde et al. 1980).

\section{HK/GK assay}

Groups of 20 isolated islets were homogenized ( 1 islet/ $\mu$ l) in $50 \mathrm{mM}$ Hepes $/ \mathrm{NaOH}$ buffer, $\mathrm{pH} 7 \cdot 5$; part of the homogenate was centrifuged for $5 \mathrm{~min}$ at $5000 \mathrm{~g}$ to remove intact cells and cell debris. The supernatant was then centrifuged for $90 \mathrm{~min}$ at $100000 \mathrm{~g}$ at $4{ }^{\circ} \mathrm{C}$ to separate the particulate (pellet) and cytosolic (supernatant) fractions. The pellet was then suspended in $150 \mu \mathrm{l}$ of the same buffer; $20 \mu \mathrm{l}$ of homogenate, pellet or cytosol were combined with another $20 \mu \mathrm{l}$ of the reaction mixture
(Hepes/NaOH, $10 \mathrm{mM}$ ATP, $20 \mu \mathrm{Ci} / \mathrm{ml} \quad(300 \mu \mathrm{Ci} /$ mmol) D- $\left[\mathrm{U}_{-}{ }^{14} \mathrm{C}\right]$ glucose and 1 or $100 \mathrm{mM}$ unlabelled D-glucose) and incubated for $60 \mathrm{~min}$ at $37^{\circ} \mathrm{C}$. The reaction was stopped by the addition of $1 \mathrm{ml}$ iced water and the medium was then passed through a column of AG $1-\mathrm{X} 8$ to separate $\mathrm{D}-\left[\mathrm{U}_{-}{ }^{14} \mathrm{C}\right] \mathrm{glucose}$ 6-phosphate from $\mathrm{D}-\left[\mathrm{U}-{ }^{14} \mathrm{C}\right]$ glucose by ion exchange chromatography (Giroix et al. 1984). The hexose phosphate was eluted from the column with $1 \mathrm{M}$ ammonium formate $/ 0 \cdot 1 \mathrm{M}$ formic acid. The eluate was mixed with scintillation fluid (Ultima Gold XR; Packard), measuring its radioactivity in a liquid scintillator spectrophotometer. The same mixture but without islet tissue was used as a blank.

\section{Western blotting}

Isolated islets were homogenized in Tris-buffered saline

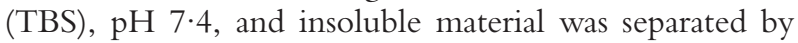
centrifugation. Protein concentration was quantified by Bio-Rad protein assay (Bradford 1976). Thereafter, dithiothreitol and bromophenol blue were added at final concentrations of $100 \mathrm{mM}$ and $0 \cdot 1 \%$, respectively.

Cellular protein from both experimental groups (HK, 10, 20 and $40 \mu \mathrm{g}$; GK, 2.5, 5 and $10 \mu \mathrm{g}$ ) was placed on reducing $7 \cdot 5 \%$ SDS/PAGE and electroblotted to PVDF membranes. Nonspecific binding sites were blocked with a non-fat milk solution at $4{ }^{\circ} \mathrm{C}$. Enzyme measurements were performed by immunoblots using the specific primary antibodies against HK (mouse anti-type I HK monoclonal antibody; Chemicon International, Temecula, CA, USA; Schwab \& Wilson 1988) or GK (sheep antiglutathione S-transferase-GK fusion protein antibody; kindly provided by Dr Mark Magnusson, Vanderbilt University, Nashville, TN, USA; Tiedge et al. 1997) at a 1:2000 final dilution. After rinsing with TBS, the sheets were further incubated with the streptavidin-peroxidase conjugated anti-mouse or anti-sheep Ig $\mathrm{G}$ for $1 \mathrm{~h}$ and were rinsed in TBS; diaminobenzidine (Sigma Chemical Co) was added for color development. Finally, band density (HK, $40 \mu \mathrm{g}$; GK, $10 \mu \mathrm{g}$ ) was measured using a Kodak DC290 digital camera and the Kodak 1D image analysis software.

\section{Isolation of total RNA and expression of $H K$ and $G K$ $m R N A$}

Total RNA was separately obtained from SRD and C islets using TRIzol reagent (Gibco-BRL; Chomczynsky \& Sacchi 1987). The integrity of isolated RNA was checked by $1 \%$ agarose/formaldehyde gel electrophoresis (Sambrook et al. 1989). Possible contamination with protein or phenol was controlled by measuring the 260/280 nm absorbance ratio, while DNA contamination was avoided using DNase I (Gibco-BRL). Reverse transcriptase (RT)-PCR was performed using SuperScript III RT (Gibco-BRL) and total RNA (50 ng) from SRD and 
C islets as a template. Since the GK and HK sequence in hamster has not been reported, we used specific primers based on the rat cDNA sequence to measure mRNA of these two enzymes (GenBank accession numbers: GK, M25807, sense primer, 5'-TGACAGAGCCAGGATG GAG-3'; antisense primer, 5'-TCTTCACGCTCCACT GCC-3' (Schuit et al. 1999); HK, NM012734, sense primer, 5'-GGCTCAGAGGAGACCCTTCG-3'; antisense primer, 5'-CCAGGTCGAACTTGAATCAT-3' (Jonas et al. 1999)). Under these assay conditions, we could not detect any band corresponding to hamster HK mRNA; therefore, we used degenerate primers obtained by comparison of the highly conserved sequence of nucleotides of this enzyme in humans, mice and rats (sense primer, 5'-TTACC(C/T)GTGGGATTCAC(A/G)TT-3'; antisense primer, $5^{\prime}-(\mathrm{A} / \mathrm{G})$ ATGATCAGGCCGACTT CAC- $3^{\prime}$ ).

Degenerate primers were designed using the Primer 3 software (Whitehead Institute, Cambridge, MA, USA and Howard Hughes Medical Institute, Chevy Chase, MD, USA) with the following restriction: oligonucleotide length of $20-25$ bases, GC content of $50-60 \%$, and product length of 200-600 bases.

$\alpha$-Tubulin was used as an internal control (sense primer, 5'-CTCGCATCCACTTCCCTC-3'; antisense primer, 5'-ATGCCCTCACCCACGTAC-3'; Jonas et al. 1999). Possible contamination with genomic DNA was checked by RT-PCR with or without the SuperScript III RT.

The cycling profile for $\mathrm{GK}$ had the following sequence: $2.5 \mathrm{~min}$ at $95{ }^{\circ} \mathrm{C}, 1 \mathrm{~min}$ at $94{ }^{\circ} \mathrm{C}, 1.5 \mathrm{~min}$ at $65^{\circ} \mathrm{C}$ and $1.5 \mathrm{~min}$ at $72{ }^{\circ} \mathrm{C}$ for 10 cycles and $0.5 \mathrm{~min}$ at $94^{\circ} \mathrm{C}, 1 \mathrm{~min}$ at $60{ }^{\circ} \mathrm{C}$ and $1.5 \mathrm{~min}$ at $72{ }^{\circ} \mathrm{C}$ for 21 cycles, bringing the total number of cycles to 31 (Schuit et al. 1999). The PCR conditions for HK were $10 \mathrm{~min}$ denaturing step at $94{ }^{\circ} \mathrm{C}$, $1 \mathrm{~min}$ at $94{ }^{\circ} \mathrm{C}, 1 \mathrm{~min}$ at $48^{\circ} \mathrm{C}$ and $1 \mathrm{~min}$ at $72{ }^{\circ} \mathrm{C}$ for four cycles, followed by $1 \mathrm{~min}$ at $94{ }^{\circ} \mathrm{C}, 1 \mathrm{~min}$ at $58^{\circ} \mathrm{C}$ and $1 \mathrm{~min}$ at $72{ }^{\circ} \mathrm{C}$ for 31 cycles, bringing the total number of cycles to 35 cycles, and a final extension step of $10 \mathrm{~min}$ at $72{ }^{\circ} \mathrm{C}$. Under these conditions, the PCR had a linear range of amplification. PCR products were separated by electrophoresis on a $2 \%(\mathrm{w} / \mathrm{v})$ agarose gel and stained with ethidium bromide. Band density was measured as described above.

\section{Statistical analysis}

The experimental data were analyzed using the Student's $t$-test. Differences were considered significant when $P<0 \cdot 05$.

\section{Results}

Body weight and water intake

Comparable body weights were recorded in SRD and $\mathrm{C}$ animals $(58.50 \pm 3.40$ compared with $53 \cdot 20 \pm 4 \cdot 00 \mathrm{~g}$,

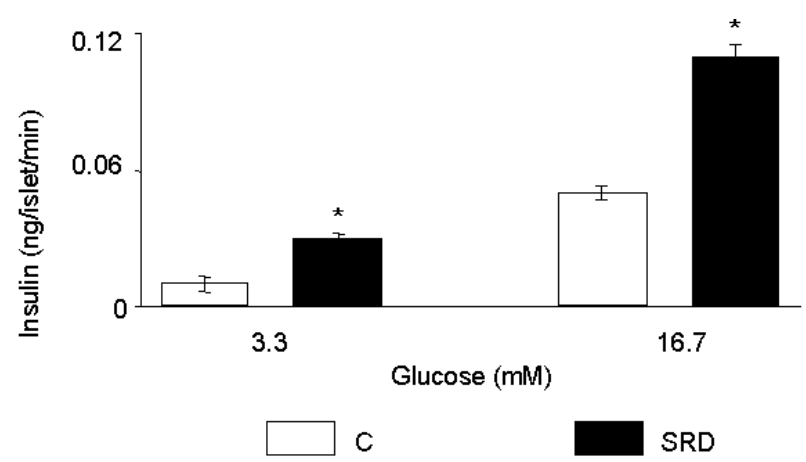

Figure 1 Effect of glucose on insulin secretion in isolated islets. Results represent means \pm S.E.M. from four different experiments performed with islets isolated from each experimental group $\left({ }^{*} P<0 \cdot 001\right) . \square, C ; \square$, SRD.

respectively; $n=20$ ). SRD hamsters drank a significantly larger volume of water than C $(33.50 \pm 3.02$ and $24 \cdot 50 \pm 2 \cdot 40 \mathrm{ml} /$ day; $P<0 \cdot 05)$. This fact resulted in a different daily intake of nutrients in the SRD and C groups (carbohydrates/proteins/lipids, 61:30:9 compared with 45:43:12, respectively).

\section{Blood glucose and serum insulin levels}

There were no significant differences in the glucose levels between the groups: SRD compared with C, $115 \pm 5 \cdot 1$ and $110 \pm 3.4 \mathrm{mg} / \mathrm{dl} ; n=20$. Conversely, SRD hamsters evinced higher serum insulin levels than $C$ hamsters $(11.50 \pm 1.52$ compared with $3.58 \pm 1.10 \mathrm{ng} / \mathrm{ml} ; n=20$; $P<0 \cdot 001)$.

Since glycemias were comparable in SRD and C animals, the uneven serum insulin values increased the insulin/ glucose molar ratio in SRD compared with $\mathrm{C}$ hamsters $\left(1 \cdot 0 \times 10^{-5}\right.$ compared with $3 \cdot 2 \times 10^{6}$, respectively).

\section{Insulin secretion}

Isolated islets incubated with high glucose released significantly more insulin than those incubated with low glucose in either group of animals. On the other hand, SRD islets released significantly larger amounts of insulin than $\mathrm{C}$ ones in response to either low or high glucose $(3.3 \mathrm{mM}$ glucose, $0.03 \pm 0.002$ compared with $0.01 \pm 0.003 \mathrm{ng}$ insulin/islet per $\mathrm{min} ; \quad P<0.001 ; 16.7 \mathrm{mM}$ glucose: $0 \cdot 11 \pm 0.005$ compared with $0.05 \pm 0.003 \mathrm{ng}$ insulin/islet per min; $n=9 ; P<0 \cdot 001$; Fig. 1 ).

\section{$H K$ and GK activity}

The rate of glucose phosphorylation measured in islet homogenates at $1 \mathrm{mM}$ glucose was compatible with the participation of a HK-like enzyme, while at $100 \mathrm{mM}$ glucose it was compatible with the participation of a GK-like enzyme. HK activity measured in SRD islets was 

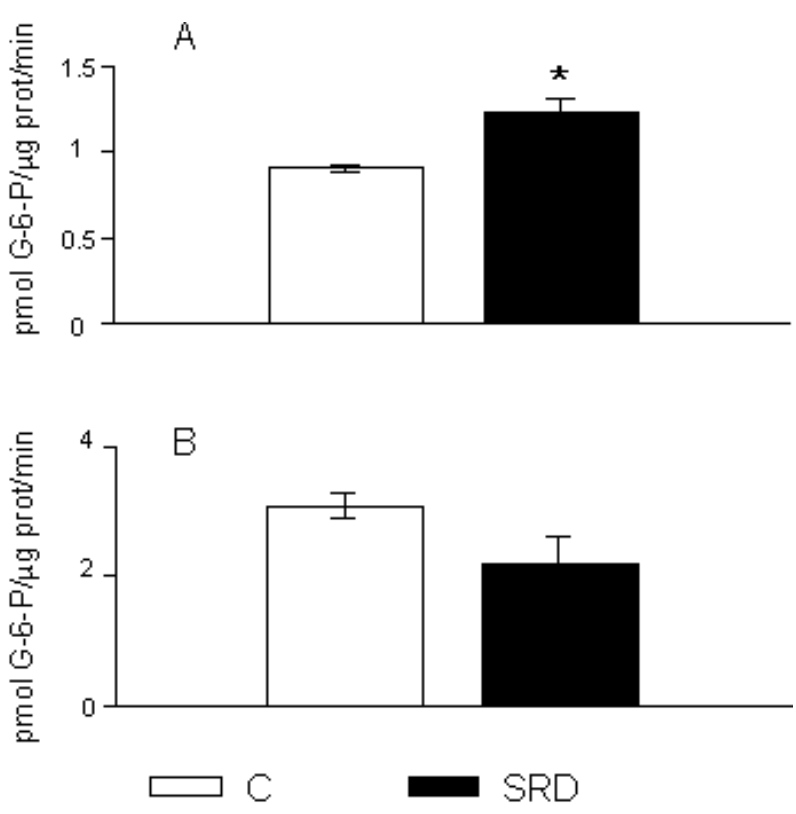

Figure 2 Glucose phosphorylation in islet homogenates at 1 (A) and 100 (B) $\mathrm{mM}$ glucose. Results represent means \pm S.E.M. from five different experiments performed with islets isolated from each experimental group, ${ }^{*} P<0 \cdot 001$. Glucose phosphorylation was measured as pmol glucose 6-phosphate/ $\mu$ g protein per min. $\square$, C; 口, SRD.

$37 \%$ higher than in $\mathrm{C}$ islets $(1.25 \pm 0.08$ and $0.91 \pm$ $0.018 \mathrm{pmol}$ glucose 6 -phosphate/ $\mu \mathrm{g}$ protein per min; $P<0 \cdot 001$; Fig. 2A). Conversely, no significant differences were found in islet GK activity between groups $(2 \cdot 17 \pm$ 0.45 and $3.06 \pm 0.21$ pmol glucose 6 -phosphate/ $\mu \mathrm{g}$ protein per min; Fig. 2B). The HK/GK activity ratio was significantly higher in SRD than in $C$ hamsters $(0 \cdot 42 \pm 0 \cdot 03$ compared with $0 \cdot 28 \pm 0 \cdot 01 ; P<0 \cdot 001)$. We also measured GK activity in the cytosol and in the particulate cell fractions, and referred to the activity measured in the whole homogenate. In this case we found that in SRD animals $100 \%$ of the GK activity was present in the cytosolic fraction $(2.65 \pm 0.24$ out of $2.17 \pm$ $0.45 \mathrm{pmol} / \mu \mathrm{g}$ per min), while in $\mathrm{C}$ hamsters this fraction represented $53 \%$ of the activity measured in the homogenate $(1.62 \pm 0.36$ out of $3.06 \pm 0.36 \mathrm{pmol} / \mu \mathrm{g}$ per $\mathrm{min})$. Further, the difference in the GK activity measured in this fraction was significantly higher in SRD animals $(P<0 \cdot 025)$.

\section{Western blotting}

Western blotting performed in homogenates of islets from SRD and C hamsters with specific HK and GK antibodies showed single bands of about 109 and $50 \mathrm{kDa}$ respectively, compatible with the molecular masses of the enzymes. Band intensity increased as a function of the protein concentration used, supporting the reliability, specificity and measurability of the immunoreaction (data not shown).

Whereas the intensity of the HK band was higher in SRD than in C animals (201 and 100\%; Fig. 3A and C), no differences were found in the intensity of the GK band (107 and 100\%; Fig. 3B and D).
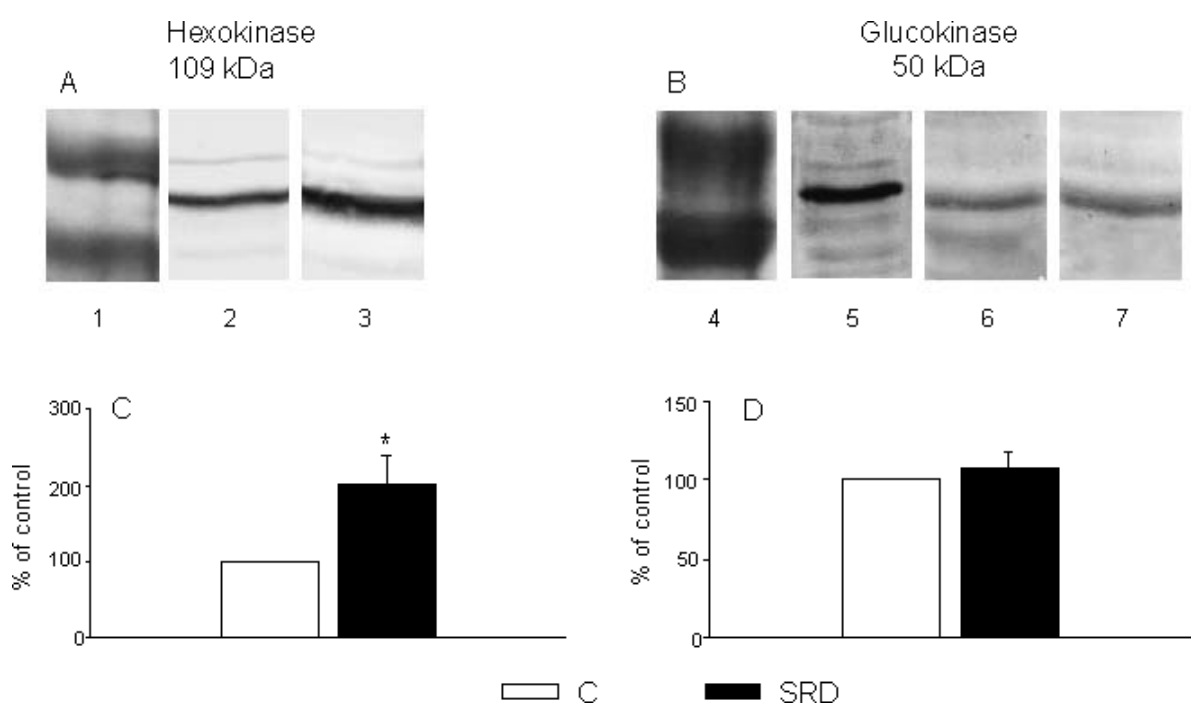

Figure 3 HK (A) and GK (B) expression in islet homogenates from C (lanes 2 and 6) and SRD (lanes 3 and 7) animals. In both cases, molecular-mass standards were used as an internal control (lanes 1 and 4), and RINm5F GK cells (lane 5) as a control for GK measurement (HK and GK protein concentrations, 40 and $10 \mu \mathrm{g}$, respectively). Band intensities of HK (C) and GK (D) were measured in SRD ( $\mathbf{\square})$ and $\mathrm{C}(\square)$ animals. Blots representative of four independent experiments are shown. 
A.
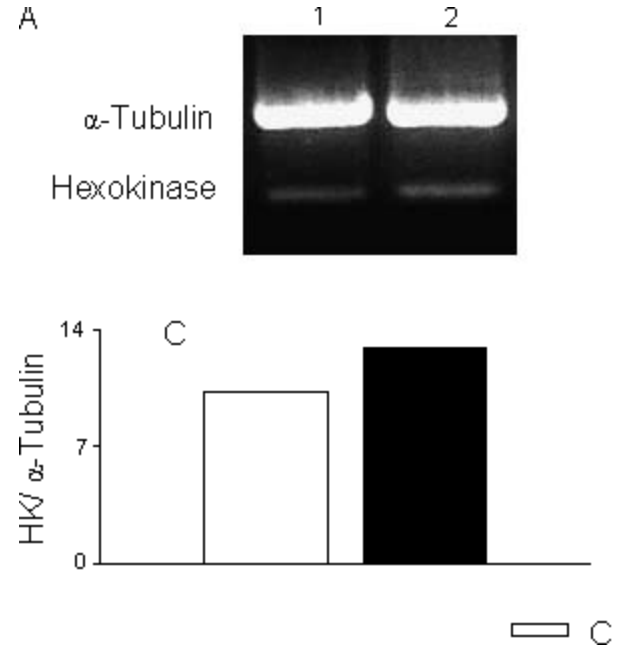
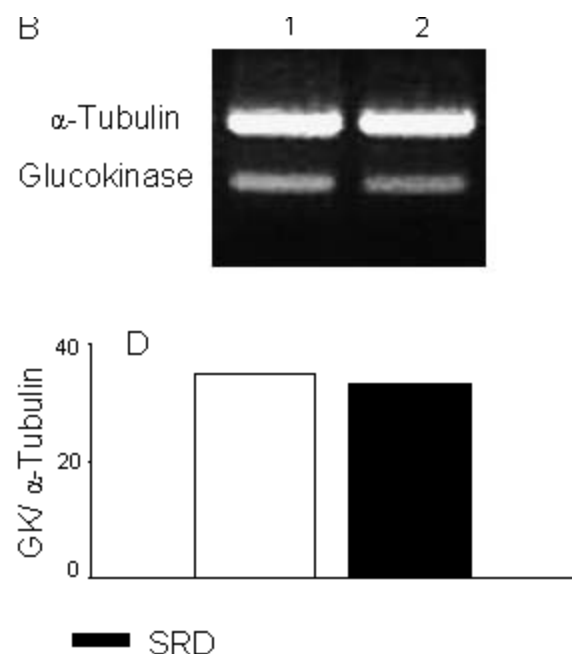

Figure $4 \mathrm{HK}(\mathrm{A})$ and GK (B) mRNA in isolated islets from C (lanes 1) and SRD (lanes 2) hamsters. Band intensities are expressed as the ratio of the band intensities of HK (C) or GK (D) to $\alpha$-tubulin products. $\square, \mathrm{C} ; \boldsymbol{\square}, \mathrm{SRD}$.

\section{$R T-P C R$}

The RT-PCR procedure with total RNA from SRD and $\mathrm{C}$ islets did not show differences in the intensity of the bands corresponding to GK and HK mRNA compared with $\alpha$-tubulin (SRD compared with C: HK, 13 versus $10 \cdot 2 \%$ of control (Fig. 4A and C); GK, $24 \cdot 9$ and $25 \cdot 9 \%$ of control (Fig. 4B and D)).

\section{Discussion}

In this study, sucrose-treated animals released more insulin than controls in response to low or high glucose either in vitro or in vivo (normoglycemia with hyperinsulinemia), thus supporting our previously reported findings using this experimental model (Massa et al. 1997, 2001, Del Zotto et al. 1999).

Glucose phosphorylation is the rate-limiting step for glucose metabolism in the islets and the consequent release of insulin (Ashcroft et al. 1970, Lenzen \& Panten 1988, Matschinsky 1990, Lenzen 1992). The process is accomplished by two enzymes with high and low affinity for glucose (HK and GK, respectively; Lenzen \& Panten 1988). The presence of these two kinases enables $\beta$-cells to effectively phosphorylate glucose within a wide range of glucose concentrations, thus linking the release of insulin efficiently and tightly with the environmental glucose level.

Our results showed a significant increase in both HK activity and expression levels in SRD islets (37 and 100\%, respectively) without changes in its transcriptional rate (amount of mRNA). Conversely, we found a similar activity in islets homogenates, GK transcriptional rate and expression level.

It has been reported that an overloaded $\beta$-cell function increases HK activity and the HK/GK ratio in the islets (Leahy 1996). These changes modify the glucose set-point for insulin secretion, rendering $\beta$-cells hypersensitive to glucose stimulation (Lenzen \& Panten 1988, Epstein et al. 1992, Lenzen 1992, Newgard 1992, Hosokawa et al. 1995, Leahy 1996). We have previously reported that normal hamsters fed a SRD develop an insulin-resistance state that triggers functional and morphological changes in the endocrine pancreas (Massa et al. 1997, Del Zotto et al. 1999, 2000, Gagliardino et al. 2003). Among these changes, we found an increased $\mathrm{HK} V_{\max }$ - without any significant changes in GK $V_{\max }-$ and HK/GK activity-ratio. These changes were accompanied by a significant increase of glucose metabolism and a shift to the left in the doseresponse curve of glucose-induced insulin secretion (Massa et al. 2001). As a counterpart of all these changes in vitro, the animals had normal blood glucose levels and a significantly increased serum insulin/glucose ratio, the latter representing the successful pancreas effort to overcome the decreased insulin-sensitivity of peripheral tissues (Reaven 1988).

The activity of HK I can be modified by altering either the rate of gene transcription or its ATP affinity and sensitivity to glucose 6-phosphate (Epstein et al. 1992, Becker et al. 1996). Since HK mRNA was similar in SRD and $\mathrm{C}$ animals, the increased activity measured in SRD islets would depend on changes occurring at the posttranscriptional level. In fact, the significant increase in HK protein level could explain the previously reported and reproducable increase in HK activity in SRD islets. While these changes could explain the increased glucose 
metabolism/release of insulin observed in SRD animals in response to low glucose, they cannot account for the increase observed in the presence of high glucose.

GK activity measured in islet homogenates, gene transcription and protein expression rates were similar in $\mathrm{C}$ and SRD hamsters. These results would not explain the increased release of insulin of the latter group in response to high glucose. We should therefore look for an alternative explanation. It has been reported that posttranslational modulation of GK function could be related to its compartmentalization in the cytoplasm and $\beta$-cell granules (Rizzo et al. 2002) or to its interaction with 6-phosphofructo-2-kinase/fructose-2,6-bisphosphatase (Massa et al. 2004). GK compartmentalization in insulinsecreting cells has been described by several research groups (Vanhoutte et al. 1997, Stubbs et al. 2000, Rizzo et al. 2002, Arden et al. 2004). Apparently, GK release from the granule-bound state to cytoplasm is accompanied by an increase in its activity (Rizzo et al. 2002); that is, the enzyme activity is lower when associated with insulin granules and higher when released into the cytoplasm. In our study, the percentage of GK activity measured in the cytosol was significantly higher in SRD hamsters; thus, this different compartmentalization of the enzyme could account for the higher glucose metabolism/release of insulin found in these animals in response to high glucose. Although the physiological role of GK compartmentalization under an acute glucose stimulus remains controversial, our results suggest that it could become important in the process of long-term adaptation, such as in the case of animals fed a SRD.

There is no clear explanation at present for the underlying mechanism by which insulin resistance triggers the changes in islet HK/GK ratio and GK compartmentalization. The stimulatory effect of insulin upon islet GK transcription (Leibiger et al. 2001) and compartmentalization (Rizzo et al. 2002) and glucose metabolism (Borelli et al. 2004) would suggest that insulin resistance could also operate at islet level.

In brief, our results show that the pancreas overload elicited in normal hamsters by the SRD-induced insulinresistance state produced a significant increase in the expression and activity of islet $\mathrm{HK}$ without affecting these parameters at GK level, but modifying its cellular compartmentalization. Posttranscriptional changes in $\mathrm{HK}$ and GK, together with an increase in $\beta$-cell mass, promote an increase in islet glucose metabolism and insulin release in response to glucose that enables the animals to maintain normoglycemia despite the decreased response of peripheral tissues to insulin. Failure of these compensatory mechanisms to pancreas overload may result in the development of a diabetic syndrome. Thus, control of islet HK activity and protein expression as well as GK compartmentalization could be useful to prevent the failure of pancreatic islets in the case of an increased demand for insulin secretion.

\section{Acknowledgements}

This study was supported by grants from the National Fund for Scientific and Technological Research (FONCYT), the National Research Council (CONICET), and the Scientific Research Commission of the Province of Buenos Aires (CICPBA). We thank Adriana Di Maggio for careful manuscript edition and Adrián Díaz for technical assistance. The authors declare that there is no conflict of interest that would prejudice the impartiality of this scientific work.

\section{References}

Arden C, Harbottle A, Baltrusch S, Tiedge M \& Agius L 2004 Glucokinase is an integral component of the insulin granules in glucose-responsive insulin secretory cells and does not translocate during glucose stimulation. Diabetes 53 2346-2352.

Ashcroft SJ, Hedeskov CJ \& Randle PJ 1970 Glucose metabolism in mouse pancreatic islets. Biochemical Journal 118 143-154.

Becker TC, Noel RJ, Johnson JH, Lynch RM, Hirose H, Tokuyama Y, Bell GI \& Newgard CB 1996 Differential effects of overexpressed glucokinase and hexokinase I in isolated islets. Evidence for functional segregation of the high and low Km enzymes. Journal of Biological Chemistry 271 390-394.

Borelli MI, Francini F \& Gagliardino JJ 2004 Autocrine regulation of glucose metabolism in pancreatic islets. American Journal of Physiology Endocrinology and Metabolism 286 E111-E115.

Bradford MM 1976 A rapid and sensitive method for the quantitation of microgram quantities of protein utilizing the principle of protein-dye binding. Analytical Biochemistry 72 248-254.

Chomczynsky P \& Sacchi N 1987 Single-step method of RNA isolation by acid guanidinium thiocyanate-phenol-chloroform extraction. Analytical Biochemistry 162 156-159.

Cohen AM, Teitelbaum A \& Rosenman E 1977 Diabetes induced by a high fructose diet. Metabolism 26 17-24.

DeFronzo RA 1997 Pathogenesis of type 2 diabetes: metabolic and molecular implications for identifying diabetes genes. Diabetes Reviews 5 177-269.

Del Zotto H, Massa L, Gómez Dumm CL \& Gagliardino JJ 1999 Changes induced by sucrose administration upon the morphology and function of pancreatic islets in the normal hamster. Diabetes Metabolism Research and Reviews 15 106-112.

Del Zotto H, Massa L, Rafaeloff R, Pittenger GL, Vinik A, Gold G, Reifel-Miller A \& Gagliardino JJ 2000 Possible relationship between changes in islet neogenesis and islet neogenesis-associated protein-positive cell mass induced by sucrose administration to normal hamsters. Journal of Endocrinology 165 725-733.

Epstein PN, Boschero AC, Atwater I, Cai X \& Overbeek PA 1992 Expression of yeast hexokinase in pancreatic beta cells of transgenic mice reduces blood glucose, enhances insulin secretion, and decreases diabetes. PNAS 89 12038-12042.

Gagliardino JJ \& Olivera EM 2000 Economics of diabetes in low-income populations: overview of Latin America and the Caribbean. In The Economics of Diabetes Care. An International Perspective, pp 41-59. Eds R Williams, J Tuomilehto \& S Bjork. Oxford, UK: Blackwell Science.

Gagliardino JJ, Nierle C \& Pfeiffer EF 1974 The effect of serotonin on in vitro insulin secretion and biosynthesis in mice. Diabetologia $10411-414$.

Gagliardino JJ, Del Zotto H, Massa L, Flores L \& Borelli MI 2003 Pancreatic duodenal homeobox-1 and islet neogenesis-associated protein: a possible combined marker of activateable pancreatic cell precursors. Journal of Endocrinology 177 249-259. 
Giroix MH, Sener A, Pipeleers DG \& Malaisse WL 1984 Hexose metabolism in pancreatic islets. Inhibition of hexokinase. Biochemical Journal 223 447-453.

Herbert V, Lau KS, Gottlieb CW \& Bleicher SJ 1965 Coated charcoal immunoassay of insulin. Journal of Clinical Endocrinology and Metabolism 25 1375-1384.

Hosokawa H, Hosokawa YA \& Leahy JL 1995 Upregulated hexokinase activity in isolated islets from diabetic $90 \%$ pancreatectomized rats. Diabetes 44 1328-1333.

Jonas JC, Sharma A, Hasenkamp W, Ilkova H, Patane G, Laybutt R, Bonner Weir S \& Weir GC 1999 Chronic hyperglycemia triggers loss of pancreatic beta cell differentiation in an animal model of diabetes. Journal of Biological Chemistry 274 14112-14121.

Lacy PE \& Kostianovsky M 1967 Method for the isolation of intact islets of Langerhans from the rat pancreas. Diabetes 16 35-39.

Leahy JL 1996 Impaired B-cell function with chronic hyperglycemia: 'Overworked $\beta$-cell' hypotesis. Diabetes Reviews 4 298-319.

Leibiger B, Leibiger IB, Moede T, Kemper S, Kulkarni RN, Kahn CR, de Vargas LM \& Berggren PO 2001 Selective insulin signaling through $\mathrm{A}$ and $\mathrm{B}$ insulin receptors regulates transcription of insulin and glucokinase genes in pancreatic beta cells. Molecular Cell 7 559-570.

Lenzen S 1992 Glucokinase: Signal recognition enzyme for glucose-induced insulin secretion. In Nutrient Regulation of Insulin Secretion, pp 101-125. Ed PR Flatt. London, UK: Portland Press.

Lenzen S \& Panten U 1988 Signal recognition by pancreatic B-cells. Biochemical Pharmacology 37 371-378.

Linde S, Hansen B \& Lernmark A 1980 Stable iodinated polypeptide hormones prepared by polyacrylamide gel electrophoresis. Analytical Biochemistry 107 165-176.

Lombardo YB, Drago S, Chicco A, Fainstein-Day P, Gutman R, Gagliardino JJ \& Gómez Dumm CL 1996 Long-term administration of a sucrose-rich diet to normal rats: relationship between metabolic and hormonal profiles and morphological changes in the endocrine pancreas. Metabolism 45 1527-1532.

Massa L, Del Zotto H, Gómez Dumm CL \& Gagliardino JJ 1997 Postnatal sequential changes in islet morphology and insulin secretion of normal hamsters. Pancreas 14 58-64.

Massa L, Borelli MI, Del Zotto H \& Gagliardino JJ 2001 Changes induced by sucrose administration on glucose metabolism in pancreatic islets in normal hamsters. Journal of Endocrinology 171 551-556.

Massa L, Baltrusch S, Okar DA, Lange AJ, Lenzen S \& Tiedge M 2004 Interaction of 6-phosphofructo-2-kinase/fructose2,6-bisphosphatase (PFK-2/FBPase-2) with glucokinase activates glucose phosphorylation and glucose metabolism in insulin-producing cells. Diabetes 53 1020-1029.

Matschinsky FM 1990 Glucokinase as glucose sensor and metabolic signal generator in pancreatic beta-cells and hepatocytes. Diabetes 39 647-652.

Newgard CB 1992 Cellular engineering for the treatment of metabolic disorders: prospects for therapy in diabetes. Biotechnology 10 1112-1120.

Pick A, Clark J, Kubstrup CH, Levisetti M, Pugh W, Bonner-Weir S \& Polonsky KS 1998 Role of apoptosis in failure of beta-cell mass compensation for insulin resistance and beta-cell defects in the male Zucker diabetic fatty rat. Diabetes 47 358-364.

Reaven GM 1988 Banting lecture 1988. Role of insulin resistance in human disease. Diabetes 37 1595-1607.

Rizzo MA, Magnuson MA, Drains PF \& Piston DW 2002 A functional link between glucokinase binding to insulin granules and conformational alterations in response to glucose and insulin. Journal of Biological Chemistry 277 34163-34175.

Sambrook J, Fritsch EF \& Maniatis TE 1989 Molecular Cloning: A Laboratory Manual, 2nd edn. Cold Spring Harbor: Cold Spring Harbor Press.

Schuit F, Moens K, Heimberg H \& Pipeleers D 1999 Cellular origin of hexokinase in pancreatic islets. Journal of Biological Chemistry 274 32803-32809.

Schwab DA \& Wilson JE 1988 The complete amino acid sequence of the catalytic domain of rat brain hexokinase, deduced from the cloned cDNA. Journal of Biological Chemistry 263 3220-3224.

Stubbs M, Aiston S \& Agius L 2000 Subcellular localization, mobility and kinetic activity of glucokinase in glucose-responsive insulin-secreting cells. Diabetes 49 2048-2055.

Tiedge M, Krug U \& Lenzen S 1997 Modulation of human glucokinase intrinsic activity by $\mathrm{SH}$ reagents mirrors post-translational regulation of enzyme activity. Biochimica et Biophysica Acta 1337 175-190.

Vanhoutte C, Sener A \& Malaisse WJ 1997 Subcellular distribution of hexokinase isoenzymes in pancreatic islet cells exposed to digitonin alter incubation at a low or high concentration of D-glucose. Molecular and Cellular Biochemistry 175 131-136.

Received in final form 15 December 2005

Accepted 1 February 2006

Made available online as an Accepted Preprint 2 February 2006 